\title{
TINGKAT PENDAPATAN ANGGOTA LMDH "LANCAR JAYA" DARI SEKTOR PERTANIAN HORTIKULTURA DI DESA NGANCAR KECAMATAN NGANCAR KABUPATEN KEDIRI
}

\author{
Erda Risky Saputra, Tatag Muttaqin, Nugroho Tri Waskitho
}

\author{
Kehutanan \\ Universitas Muhammadiyah Malang \\ erdarisky13@gmail.com
}

\begin{abstract}
Abstraksi
Penelitian ini dilakukan pada tanggal 10 November 2018 - 31 Januari 2019 di Desa Ngancar, Kecamatan Ngancar, Kabupaten Kediri. Penelitian tersebut ditujukan untuk mengetahui tingkat pendapatan anggota LMDH "Lancar Jaya" di Desa Ngancar. Selain itu, untuk mengetahui faktor yang mempengaruhi keberhasilan program Lembaga Masyarakat Desa Hutan (LMDH) yang telah dilakukan dalam meningkatkan pendapatan anggota kelompok tani. Pemilihan lokasi Desa Ngancar dikarenakan wilayah tersebut merupakan salah satu daerah wisata yang memiliki jumlah penduduk miskin yang relatif masih banyak.

Metode pengumpulan data berupa data primer yang dikumpulkan dengan teknik pengamatan (observasi) secara langsung di lapangan dengan metode wawancara, kuisioner, dan studi dokumentasi terhadap responden (anggota kelompok tani) yang didapat dengan metode purposive sampling. Data sekunder dikumpulkan dengan teknik mencatat data yang sudah ada di instansi terkait. Data yang diperoleh akan diolah dengan cara perhitungan dan tabulasi. Sedangkan dalam metode analisis data, peneliti menggunakan dua cara yaitu analisis keberhasilan perekonomian (pendapatan), dan faktor keberhasilan LMDH. Untuk metode pengolahan data, kuesioner pendapatan menggunakan rumus pendapatan usaha tani $(\pi)$ yang merupakan selisih antara total penerimaan (TR) dan total biaya (TC), sedangkan kuisoner faktor keberhasilan LMDH menggunakan Skala Likert.

Berdasarkan dari hasil penelitian yang dilakukan, komoditi Cabai (Capsicum annum L) didapat 68 respoden dengan total pendapatan Rp. 3.337.850.000, dengan rata - rata pendapatan per Ha nya Rp. 49.086.030 dalam satu musim tanam. Sedangkan komoditi Tomat (Solanum lycopersicum L) didapat 47 respoden dengan total pendapatan Rp. 1.368.899.000, dengan rata - rata pendapatan per Ha nya Rp. 29.125.510 dalam satu musim tanam.
\end{abstract}

Kata kunci: pendapatan, faktor, LMDH

\section{PENDAHULUAN}

Amanat yang tertuang dalam UndangUndang Dasar Republik Indonesia tahun 1945 menyatakan bahwa seluruh sumber daya dan kekayaan alam berada di bawah kekuasaan negara. Meskipun ketentuan hukum menempatkan otoritas terhadap sumber daya alam tersebut pada berbagai level pemerintahan, hak dan tanggung jawab untuk mengelola hutan tetap dipegang oleh institusi pemerintah selama bertahun-tahun lamanya. Hal ini ternyata tidak efektif dalam mengurangi tingkat deforestasi di Indonesia dan penduduk desa yang tinggal di sekitar hutan pun tetap hidup dalam kemiskinan. Tanpa adanya hak kepemilikan, akses, dan pengelolaan (property rights), mereka tidak dapat menikmati hasil sumber daya hutan secara legal dan pada akhirnya justru tergoda untuk berpartisipasi dalam 
eksploitasi sumber daya hutan secara ilegal seperti perburuan dan penebangan liar (Perum Perhutani. 2008).

Beberapa tahun belakangan ini, pemerintah Indonesia secara bertahap menerapkan berbagai ketentuan tambahan dalam regulasi kehutanan Indonesia, termasuk memberikan hak bagi masyarakat setempat untuk dapat terlibat dalam pengelolaan sumber daya hutan. Guna memperoleh hak untuk mengakses dan menggunakan sumber daya hutannya, para penduduk desa diharuskan untuk mendirikan Lembaga Masyarakat Desa Hutan (LMDH) dan berbagi hasil keuntungannya dengan pemerintah. Pemerintah berencana untuk memberikan konsesi kepada 33.000 desa di seluruh Indonesia sebagai bagian dari kebijakan Skema Perhutanan Sosial. Meski demikian, pemberian konsesi saja tidak akan mengurangi deforestasi dan meningkatkan kesejahteraan masyarakat desa, melainkan harus didukung oleh berbagai kegiatan pelengkap yang membantu penerapan kebijakan hutan kemasyarakatan tersebut (Perum Perhutani. 2009)

Hutan rakyat memiliki peran penting dalam kehidupan masyarakat Indonesia, baik peran ekonomi, ekologi, sosial maupun budaya. Mindawati (2006) mengemukakan hutan rakyat berperan dalam meningkatkan pendapatan masyarakat, memperbaiki kondisi lahan dan lingkungan serta memperluas kesempatan kerja. Keberhasilan usaha tani hutan rakyat di Indonesia akan berdampak positif terhadap pembangunan nasional Indonesia seperti peningkatan kesejahteraan masyarakat khususnya petani, perbaikan lingkungan hidup dan peningkatan keamanan hutan.

Pelaksanaan program PHBM harus dilakukan secara optimal agar dapat mengurangi kerusakan hutan. Oleh karena itu, diperlukan peran dan dukungan dari LMDH (Lembaga Masyarakat Desa Hutan) sebagai wadah bagi masyarakat desa hutan untuk ikut serta dalam pengelolaan hutan. LMDH melakukan upaya pendekatan kepada masyarakat serta memberdayakan masyarakat desa hutan sehingga dapat mengurangi terjadinya pencurian. Pencurian tersebut lebih dominan dilakukan karena kebutuhan ekonomi, sehingga melalui LMDH dan PHBM ini pemberdayaan tersebut dapat memberikan nilai ekonomi bagi masyarakat sekitar hutan (Perum Perhutani. 2009).

PHBM yang dilakukan di desa Ngancar dimulai sudah sejak lama, tanamannya merupakan tanaman rimba campuran seperti: sengon, jabon, jati dll. Untuk Desa Ngancar, tanaman sengon lebih dominan karena topografi berupa pegunungan. Di desa ini masyarakat mengelola hutan dengan sistem agroforestry biasanya tanaman yang ditanam seperti jagung, cabai, nanas, tomat, buncis dan belum dilakukan evaluasi tingkat keberhasilannya.

\section{METODE}

Penelitian ini dirancang dengan metode kualitatif dan kuantitatif. Disebut penelitian kualitatif karena peneliti akan mendeskripsikan hasil yang diperoleh atas pokok masalah yang dipilih, yaitu berupa keberhasilan dan peningkatan pendapatan masyarakat sekitar hutan melalui pengembangan program LMDH (Lembaga Masyarakat Desa Hutan). Pada pendekatan kuantitatif, peneliti akan menganalisis jumlah keberhasilan dan peningkatan pendapatan masyarakat sekitar hutan melalui program LMDH. Jumlah tersebut diidentifikasi dengan beberapa tahapan jenis kegiatan kelompok tani di ladang, yaitu pengelolaan tanah, pembibitan/penyemaian, pemeliharaan 
tanaman, pemanenan, hingga pengolahan hasil tanaman.

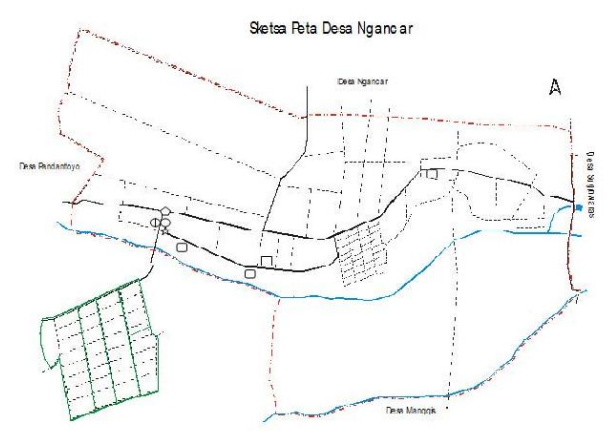

Lokasi penelitian

Data yang dikumpulkan dalam penelitian ini terdiri dari data primer dan data sekunder. Data primer diperoleh dari pengamatan langsung terhadap status sosial, demografi responden, sistem dan teknik silvikultur pengusahaan hutan, biaya dan pendapatan pengusahaan hutan, dan sosial budaya masyarakat. Data primer dikumpulkan dengan teknik pengamatan (observasi) secara langsung di lapangan dengan metode wawancara, kuisioner, dan studi dokumentasi terhadap anggota kelompok tani yang didapat dengan metode purposive sampling. Untuk menetapkan jumlah sampel dapat menggunakan rumus dengan metode purposive sampling (Zainuddin, 2002: 58).

Dalam menganalisis data, peneliti menggunakan dua cara yaitu analisis keberhasilan perekonomian, dan analisis pengembangan perekonomian. Analisis keberhasilan perekonomian menggunakan perhitungan pendapatan usaha tani. Adanya manfaat ekonomi oleh LMDH diperoleh dari masing-masing pihak dengan dilakukan pencarian data dari instansi dan wawancara langsung dengan responden, dan dianalisis secara kuantitatif. Perhitungan manfaat ekonomi dari usaha tani tersebut menggunakan analisis pendapatan. Pendapatan usaha tani $(\pi)$ merupakan selisih antara penerimaan (TR) dan semua biaya (TC) (Soekartawi, 2002).

Perhitungan pendapatan tersebut, akan diperoleh kesimpulan bahwa jika TR > $\mathrm{TC}$, maka petani memperoleh keuntungan. Akan tetapi, jika TR $<$ TC, maka petani mengalami kerugian. Dari hasil tersebut akan dibandingkan dengan pendapatan musim sebelumnya, sehingga melalui cara tersebut, diharapkan dapat menunjukkan tingkat persentase keberhasilan perekonomian anggota LMDH "Lancar Jaya" di Desa Ngancar.

Untuk mengolah data dari kuisoner faktor LMDH, peneliti menggunakan metode Skala Likert. Apabila hasil akhir diperoleh kurang dari $60 \%$, maka dapat disimpulkan tingkat keberhasilan LMDH masih lemah. Sehingga perlu untuk dilakukan pengembangan serta pembenahan. Akan tetapi, jika hasil akhir diperoleh lebih dari $60 \%$, maka dapat disimpulkan bahwa tingkat keberhasilan LMDH adalah kuat. Sehingga perlu untuk dipertahankan serta dilakukan pengembangan agar keberhasilannya meningkat.

\section{HASIL DAN PEMBAHASAN}

\section{Karakteristik Responden (Kelompok Tani)}

Terdapat beberapa karakter yang dimiliki oleh responden yakni kelompok tani di Desa Ngancar, Kecamatan Ngancar, Kabupeten Kediri. Kelompok tani tersebut dipilih menjadi 90 orang sebagai responden yang memiliki kesesuaian indikator dalam penelitian ini. Pemilihan karakter yang dimaksud, diidentifikasi melalui beberapa aspek antara lain, karakteristik responden berdasarkan usia, tingkat pendidikan, luas kepemilikan lahan, jumlah tanggungan keluarga, 
pekerjaan utama, serta pendapatan ratarata tiap responden.

\section{Usia Responden}

Umur mempengaruhi kemampuan kerja seseorang, semakin bertambahnya usia maka kemampuan kerja akan semakin menurun. Umur responden berkisar antara 21-70 tahun, dengan presentase terbesar responden berada pada umur 21-30 tahun yaitu sebesar $36.7 \%$. Umur produktif untuk bekerja di negara-negara berkembang umumnya adalah 15-55 tahun. Berdasarkan hasil penelitian yang diperoleh, responden dengan persentase $36.7 \%$ masuk ke dalam usia produktif.

\section{Tingkat Pendidikan}

Sebagian besar tingkat pendidikan responden adalah Sekolah Menegah Pertama (SMP) yaitu sebanyak 41,1 \% sedangkan jumlah responden dengan yang tidak memiliki tingkat pendidikan atau tidak bersekolah terdapat $0 \%$ atau berjumlah 0 orang. Hal ini berarti bahwa tingkat pendidikan responden di Desa Ngancar masih tergolong rendah. Tingkat pendidikan sangat berpengaruh dalam praktek pengelolaan hutan rakyat yang mereka miliki. Semakin tinggi tingkat pendidikan, maka pengelolaan hutan rakyatnya akan semakin baik pula.

\section{Luas Kepemilikan Lahan}

Dalam mengelola suatu usaha maka tidak terlepas dari penguasaan lahan oleh petani yang berpengaruh terhadap besar kecilnya pendapatan yang diterima. Responden di Desa Ngancar dalam melakukan usaha tani miliknya, mereka menggunakan lahan miliknya sendiri untuk dikelola termasuk lahan hutan rakyat dengan luas terkecil dari keseluruhan responden adalah 0,10 ha dan terbesar adalah 1 ha. Berdasarkan hasil penelitian yang dilakukan, luas kepemilikan lahan di Desa Ngancar masih tergolong sempit. Hal ini dapat dilihat dari persentase luas kepemilikan lahan dari total responden 90 orang, 57 orang diantaranya memiliki luas kurang dari 0,40 ha dan hanya 12 orang yang memiliki luas lahan lebih dari 0.70 ha. Lahan tersebut sebagian besar ditanami dengan tanaman cabai dan tomat. Tanaman yang paling banyak ditanam adalah cabai yaitu dimiliki oleh 42 responden, sedangkan tomat berjumlah paling sedikit yaitu dimiliki 22 responden.

\section{Jumlah Tanggungan Keluarga}

Pada umumnya, setiap rumah tangga

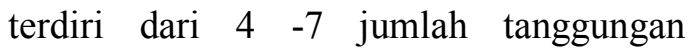
keluarga. Akan tetapi, masyarakat di Desa Ngancar rata-rata memiliki anak yang sudah dewasa, sehingga banyak yang merantau atau sudah tidak tinggal bersama orang tua. Oleh karena itu, yang tersisa di rumah hanyalah orang tua dan beberapa anak yang masih kecil.

\section{Pekerjaan Utama}

Pekerjaan utama adalah pekerjaan yang dilakukan dimana intensitas kegiatan yang dilakukan lebih tinggi dibanding pekerjaan lain. Pekerjaan lain dilakukan untuk menambah pendapatan dan termasuk ke dalam jenis pekerjaan sampingan. Sebagian besar penduduk di Desa Ngancar memiliki mata pencaharian sebagai petani. Hal ini dapat dilihat dari hasil penelitian yang dilakukan, sebanyak $43,3 \%$ responden bermata pencaharian sebagai petani. Berdasarkan data tersebut menunjukkan bahwa masyarakat Desa Ngancar masih bergantung pada pertanian baik hutan, sawah maupun tanaman pertanian lainnya.

\section{Pendapatan Rata-rata anggota LMDH "Lancar Jaya"}

Berdasarkan penelitian yang dilakukan, terdapat beberapa hasil yang diperoleh. Dari tingkat pendapatan responden anggota LMDH "Lancar Jaya" di Desa Ngancar, rata-rata memiliki 
pendapatan per komoditi musiman Cabai (Capsicum annum L) yang dapat dilihat pada tabel 4.7. Untuk komoditi Cabai (Capsicum annum L) didapat 68 respoden dengan total pendapatan Rp. 3.337.850.000, dengan rata - rata pendapatan per Ha nya Rp. 49.086.030 dalam satu musim tanam.

Biasanya para petani menanam komoditi sayur ini setahun dua kali. Jadi dalam setahun terdapat dua musim tanam. Untuk komoditi Tomat (Solanum lycopersicum L) didapat 47 respoden dengan total pendapatan $\mathrm{Rp}$. 1.368.899.000, dengan rata - rata pendapatan per Ha nya Rp. 29.125.510 dalam satu musim tanam dapat dilihat pada tabel 4.8. Biasanya para petani menanam komoditi sayur ini setahun dua kali adi dalam setahun terdapat dua musim tanam. Dari hasil perhitungan per komoditi tersebut didapat rasio antara hasil komoditi cabai dan tomat yaitu Rp. 19.960.520. Hasil tersebut didapat dari selisih hasil rata - rata per Ha komoditi cabai dan hasil rata - rata per Ha komoditi tomat. Pemerolehan data dilakukan dengan cara menghitung jumlah pendapatan kotor/musim dikurangi jumlah total biaya/musim yang diperoleh dari data per-orang. Perhitungan tersebut menggunakan rumus yang sudah ditentukan pada bab sebelumnya, yaitu TR-TC dengan TR adalah Total Revenue atau total penerimaan ( $\mathrm{Rp}$ ) dan $\mathrm{TC}$ adalah Total Cost atau total biaya (Rp). Apabila TR > TC, maka petani memperoleh keuntungan. Akan tetapi, jika TR $<$ TC, maka petani mengalami kerugian.

\section{Tingkat Pendapatan}

Berdasarkan hasil penelitian yang telah dilakukan di LMDH Desa Ngancar, tingkat pendapatan kelompok tani LMDH "Lancar Jaya" di Desa Ngancar ini sangat bervariatif. Selain luas lahan yang berbeda antar individu, adanya hasil panen juga sangat berpengaruh terhadap pendapatan kelompok tani. Dalam suatu petak lahan terdapat beberapa pemilik lahan yang menanam spesies sayur yang berbeda, tanaman sayur yang sering dijumpai yaitu tanaman tomat dan cabai. Tanaman cabai yang ditanam terdapat dua jenis yaitu imperial dan imola, sedangkan untuk tomat hanya satu jenis yaitu tomat mutiara. Perbedaan luas lahan, alat dan bahan yang digunakan, pemerolehan hasil panen, serta harga jual per-panen ini lah yang dapat mempengaruhi perbedaan pendapatan petani sayur tersebut. Dalam pengamatan rata-rata petani mendapat keuntungan $50 \%$ dari hasil taninya.

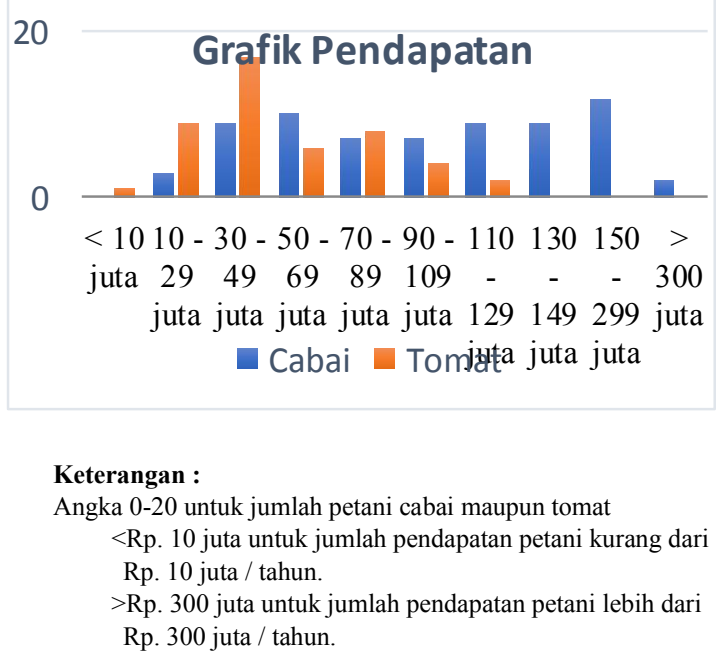

\section{Faktor Keberhasilan LMDH}

Untuk memenuhi kesejahteraan hidup anggota LMDH "Lancar Jaya" di Desa Ngancar, maka tidak lepas dari faktorfaktor yang dapat mempengaruhi keberhasilan LMDH. Adapun faktor yang menentukan keberhasilan LMDH dapat dilihat dari respon anggota LMDH dalam angket yang sudah disebarkan dan diisi oleh responden yang sudah ditentukan oleh peneliti. Berdasarkan hasil penelitian yang telah dilakukan di LMDH Desa Ngancar, dapat ditemukan beberapa faktor yang dapat mempengaruhi keberhasilan LMDH. Faktor pendukung yang pertama yaitu Lembaga Masyarakat Desa Hutan 
(LMDH) sebagai Organisasi berbadan Hukum sehingga memudahkan interaksi antara beberapa pihak contohnya pihak Dinas Perikanan, Pertanian, Perkebunan dan Pariwisata. Kedua adalah pembangunan koperasi milik lembaga, dengan adanya koperasi ini memberikan kemudahan bagi masyarakat ataupun lembaga dalam pengembangan usaha dan pendapatan masyarakat. Faktor ketiga yaitu keaktifan dalam kegiatan pelestarian hutan (perencanaan, penanaman, pemeliharaan, dan penebangan) yang dilakukan dengan teknik yang benar.

Selain faktor pendukung, tentu saja terdapat faktor yang menghambat keberhasilan program LMDH. Pertama yaitu kurangnya partisipasi masyarakat dalam beberapa kegiatan pengelolaan hutan misalnya dalam kegiatan penyuluhan, komunikasi sosial, perawatan hutan, dan penggunaaan lahan yang benar. Baik tidaknya partisipasi masyarakat, tergantung pada bagaimana cara menangkap sesuatu informasi dan bagaimana informasi itu disampaikan. Kita dapat melihat jika informasi yang disampaikan pada masyarakat ini kurang baik atau memiliki sisi visi dan misi negatif maka partisipasi yang didapat juga kurang baik. Dan juga sebaliknya jika penyampaian yang diberika kepada masyarakat oleh pihak pemerintah ini baik, maka hasilnya juga akan baik pula. Masyarakat akan melakukan partisipasi dengan baik bila tujuan yang disampaikan jelas dengan etika dan moral yang baik.

Faktor penghambat kedua adalah belum adanya kemandirian pada LMDH. Permasalahan tersebut dapat dikarenakan Perhutani sepenuhnya sebagai fasilitator, serta kurangnya kemandirian LMDH dan masih sangat bergantung pada pihak Perhutani. Oleh karena itu, diharapkan Perhutani dapat memberikan penyuluhan ataupun pelatihan agar kemandirian dari
LMDH dapat terbentuk, sehingga menciptakan inovasi maupun menambah kreativitas dari masyarakat.

Faktor penghambat yang ketiga yaitu belum optimalnya peran petugas di lapangan dalam pemberdayaan LMDH. Dalam kegiatan sosialisasi atau pemahaman tentang $\mathrm{LMDH}$, terdapat faktor kurangnya tingkat pemahaman SDM. Oleh karena itu, perlu untuk melakukan pendekatan terhadap masyarakat seperti musyawarah atau mendiskusikan aspirasi dan keluhan masyarakat terhadap program LMDH. Faktor-faktor penghambat inilah yang perlu diperhatikan, sehingga pengelolaan hutan dapat dilakukan dengan lebih maksimal dan kelestarian hutan serta kesejahteraan masyarakat di sekitar hutan yang ada dapat segera terwujud.

\section{SIMPULAN}

Berdasarkan hasil penelitian dan pembahasan yang telah diuraikan, pada bagian ini dapat dikemukakan kesimpulan penelitian sebagai berikut:

1. Dari semua responden didapat komoditi cabai (Capsicum annum L) mempunyai rata - rata pendapatan per musim per Ha lebih besar dari komoditi tomat (Solanum lycopersicum L). Pendapatan dari komoditi cabai yaitu sebesar Rp. 49.086.030/musim per Ha, sedangkan komoditi tomat sebesar Rp. 29.125.510/musim per Ha.

2. Faktor keberhasilan LMDH "Lancar Jaya" dalam peningkatan pendapatan anggotanya adalah LMDH berkerja sama dengan instansi lain baik perhutani maupun dinas pertanian sehingga apabila terdapat masalah maupun informasi penting dari pemerintah maka banyak pihak yang 
senantiasa saling membantu. Selain itu anggota sangat aktif dalam berorganisasi sehingga semua keluh kesah dan masalah petani di lapang bisa segera teratasi.

3. Faktor penghambat keberhasilan LMDH "Lancar Jaya" dalam peningkatan pendapatan anggotanya adalah yaitu kurangnya partisipasi masyarakat dalam beberapa kegiatan pengelolaan hutan, belum adanya kemandirian pada LMDH, dan belum optimalnya peran petugas di lapangan dalam pemberdayaan LMDH.

\section{DAFTAR PUSTAKA}

Mindawati, N. 2006. Review Hasil Penelitian Hutan Rakyat. Pusat Penelitian dan Pengembangan Hutan Tanaman, Badan Penelitian dan Pengembangan Kehutanan: Jakarta.

Nazir, M. 2005. Metode Penelitian. Ghalia Indonesia. Bogor

Perum Perhutani. 2008. Implementasi Pengelolaan Hutan Bersama Masyarakat- Juli 2008. . 2009. Pedoman Pengelolaan Sumber Daya Hutan Bersama Masyarakat (PHBM)- Desember 2009.

Reksohadiprodjo, S., Brodjonegoro. 2000. Ekonomi Lingkungan: Edisi Kedua. BPFE Yogyakarta: Yogyakarta.

Utami, Nisa Nimah. 2012. Pengelolaan

Hutan Bersama Masyarakat Ditinjau dari Perspektif. Social Work Jurnal. Vol 5/no. 2. Hal. 106208 